PACS 62.20.fq, 81.40.Ef, 81.40.Lm

\title{
Enhanced ductility of ultra-fine grained metallic materials
}

\author{
I. Sabirov \\ ilchat.sabirov@imdea.org \\ IMDEA Materials Institute, Getafe, Madrid, Spain
}

The ultra-fine grained metallic materials obtained via severe plastic deformation typically show very high mechanical strength but low tensile ductility, which dramatically limits their practical utility. Significant efforts were made to improve uni-axial tensile ductility of ultra-fine grained metallic materials. The developed approaches can be divided into two main groups: the 'mechanical' and 'microstructure-based' strategies. The 'mechanical' strategies are based on idea of manipulation with testing parameters (temperature, strain rate, stress state, etc.) to delay localization of plastic deformation at macro scale. Intelligent microstructural design to suppress necking at early stages of plastic deformation is employed in 'microstructural' strategies. This work aims to provide a short overview of these approaches with an emphasis on the effects of basic deformation mechanisms, chemical composition and microstructural features. It is demonstrated that the developed strategies are able to restore the uni-axial tensile ductility of the ultra-fine grained materials to the level of their coarse-grained counterparts and even to further improve it. Special attention is paid to formability of ultra-fine grained metallic materials during deformation under complex stress state. The ultra-fine grained metallic materials can demonstrate enhanced formability in deformation under complex stress state even if their uni-axial tensile ductility is very low. This is related to activation of deformation mechanisms promoting ductility, which are not active during uni-axial tensile testing.

Keywords: ultra-fine grained metallic materials, strength, ductility, formability

\section{Повышенная пластичность ультрамелкозернистых металлических материалов}

Ультрамелкозернистые металлические материалы, полученные путем интенсивной пластической деформации, имеют очень высокую механическую прочность, но низкую пластичность при растяжении, что очень сильно ограничивает их практическую применимость. Для повышения пластичности ультрамелкозернистых металлов при одноосном растяжении были приложены значительные усилия. Разработанные подходы могут быть разделены на две основные группы, которые можно назвать «механическими» и «микроструктурно-основанными» стратегиями. «Механические» стратегии основаны на идее манипуляции параметрами испытаний (температурой, скоростью деформации, напряженным состоянием и т.д.) для задержки локализации пластической деформации в макроскопическом масштабе. В «микроструктурных» стратегиях используется разумный микроструктурный дизайн для подавления шейкообразования в ранних стадиях пластической деформации. Цель настоящей работы - представить краткий обзор указанных подходов с упором на влияние основных деформационных механизмов, химического состава и микроструктурных особенностей. Показано, что разработанные стратегии могут восстановить пластичность при одноосном растяжении ультрамелкозернистых материалов до уровня крупнозернистых материалов и даже улучшить ее дальше. Отдельное внимание уделено формуемости ультрамелкозернистых металлических материалов при деформации в условиях сложного напряженного состояния. Ультрамелкозернистые металлы могут проявлять повышенную формуемость при деформации в условиях сложнонапряженного состояния, даже если их пластичность при одноосном растяжении очень низка. Это связано с активацией деформационных механизмов, повышающих пластичность, которые не активны при испытаниях на одноосное растяжение.

Ключевые слова: ультрамелкозернистые металлические материалы, прочность, пластичность, формуемость

\section{Introduction}

The research on ultra-fine grained (UFG) metallic materials processed by severe plastic deformation (SPD) started over 25 years ago [1]. It has been well established that grain refinement down to ultra-fine or nanoscale can dramatically increase mechanical strength of the metallic materials according to the well-known Hall-Petch law [2-5]. How- 
ever, this effect is accompanied by significant drop of uniaxial tensile ductility. The elongation to failure of the UFG materials is typically just a few per cent, and the uniform deformation range is even smaller. The tensile engineeringstress - strain curve peaks at a small plastic strain and then drops precipitously as strain localization leading to failure occurs [6]. The low ductility of UFG materials is attributed to the lack of work hardening caused by their inability to accumulate dislocations because of their small grain sizes and saturation of dislocations [7-9]. However, high ductility in the UFG metallic materials is essential for metalforming operations as well as to avoid catastrophic failure in loadbearing applications during their service life. The ductility of materials is defined as the extent to which a material can be plastically deformed. Two measures of ductility will be considered below. First, uniform elongation, is the maximum strain where homogeneous plastic flow (uniform reduction of cross-sectional area) is still observed and beyond which a diffuse necking begins [6]. The uniform elongation is determined by competition between plastic flow and materials resistivity to localization of plastic flow on the macro-scale. It can be important in stretch-metalforming operations. The second measure, elongation to failure (often referred to as total elongation to fracture or engineering strain at fracture), is a sum of uniform elongation and necking elongation. The latter is controlled by competition between localized plastic flow and fracture processes. Significant research activities focused on improvement of uniaxial tensile ductility of UFG metallic materials without significant degradation of their enhanced mechanical strength. Several review articles have been devoted to approaches to improve ductility of the UFG metallic materials [10-12]. The objective of this report is to provide a brief overview of the developed strategies to improve uniaxial tensile ductility and formability of the UFG metallic materials processed by SPD.

\section{Strategies to improve tensile duc- tility of UFG metallic materials}

All strategies to improve tensile ductility of the UFG metallic materials can be divided into two main groups. The first group of methods is based on the idea of intelligent microstructural design in the UFG materials in order to improve their ductility and, therefore, can be referred to as 'microstructural' strategies. The second group of methods employ the mechanical characteristics of the UFG metallic materials, such as their work hardening ability and/or strain rate sensitivity and, therefore, can be referred to as 'mechanical' strategies. These mechanical characteristics can be varied by changing testing parameters (strain rate and/or temperature) and deformation mode. Strategies from both groups are considered below.

\subsection{Intelligent microstructural design in UFG metallic materials to improve their ductility}

Formation of bi-modal microstructures was one of the first developed strategies to increase tensile ductility of the UFG metallic materials [13]. In such microstructures, coarse
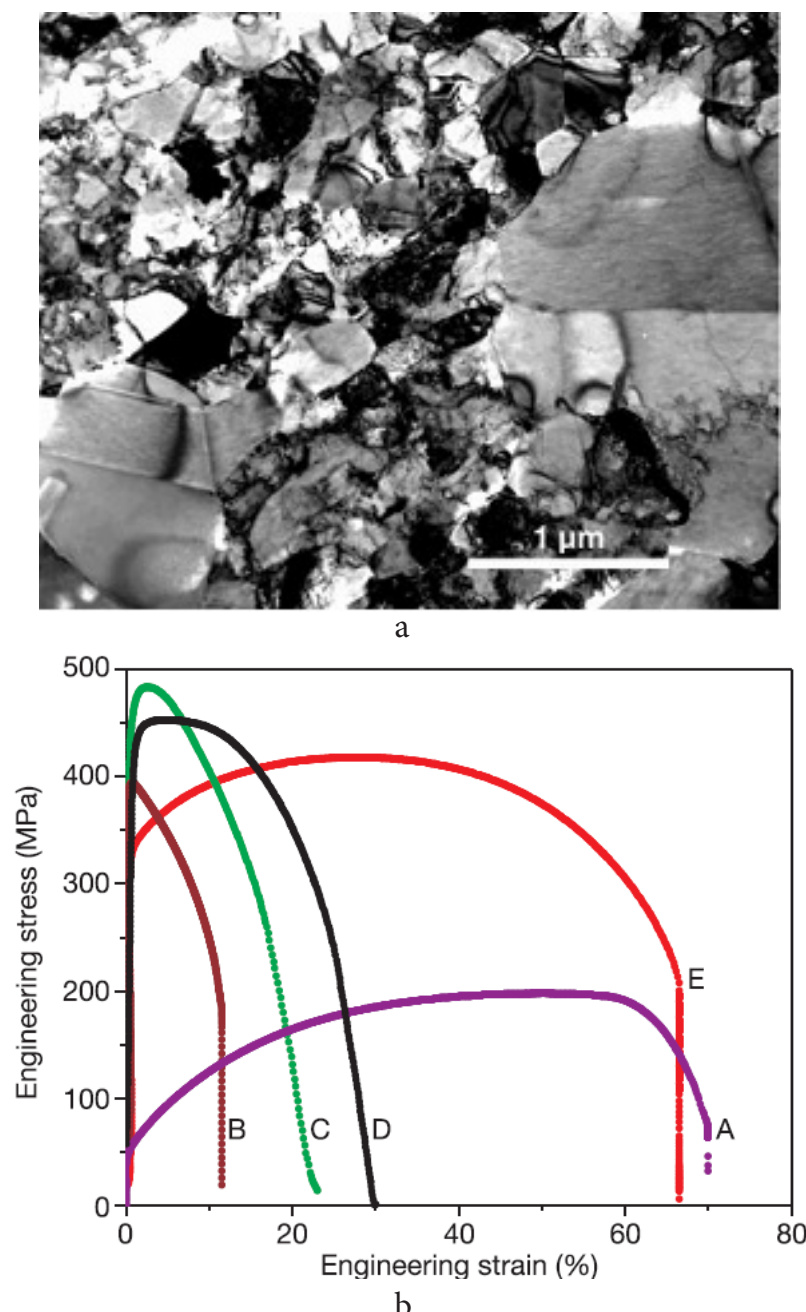

Fig. 1. (a) TEM image showing $\mathrm{Cu}$ with bimodal microstucture after 95\% cryorolling and annealing at $180 \mathrm{oC}$ for $3 \mathrm{~min}$; (b) Engineering stress - strain curves for pure $\mathrm{Cu}$ with various microstructures, where curve E presents behavior of microstructure presented on (a) [13].

grains (with a size of a few microns) are embedded in a matrix with ultrafine or nanosized grains (Fig. 1a). This can significantly increase the uniform elongation due to localization of plastic deformation in the coarser grains, thus delaying the onset of necking, whereas the matrix of ultra-fine grains provides enhanced mechanical strength. The overall strength of bi-modal microstructures is lower compared to that of their UFG counterparts. Numerous studies have been published showing that bi-modal microstructures consisting of micrograins having a size of $1-3 \mu \mathrm{m}$ and ultra-fine grains with size of $0.1-0.3 \mu \mathrm{m}$ can improve tensile ductility of pure $\mathrm{Cu}$ [13], steels [14] and Al alloys, such as AA5083 [15-18], Al$7.5 \% \mathrm{Mg}[16,19]$ and Al-Ti-Cu [20]. Cryorolling with high reduction ratio followed by short annealing at elevated temperature was applied for fabrication of bimodal microstructure in pure $\mathrm{Cu}$ [13], whereas combining cryomilled nanostructured powder with unmilled microstructured powder and their further consolidation via extrusion has been a common route for producing such microstructures in the $\mathrm{Al}$ alloys [15-20]. It was demonstrated that the relationship between yield strength of materials with bimodal microstructures and volume fraction of micro-grained powders $V$ can be roughly approximated by a rule of mixtures [21] 


$$
\sigma_{\text {bimodal }}=V \sigma_{c}+(1-V) \sigma_{n}
$$

where $\sigma_{n}$ and $\sigma_{c}$ are the yield stress of nanostructured materials processed with $100 \%$ nanostructured powders and $100 \%$ coarse-grained powders, respectively. The overall ductility of the bi-modal material increases with increasing volume fraction of micro-grains, whereas the yield strength shows an opposite trend.

It was suggested that the microstructure of bi-modal cryomilled materials processed after extrusion is analogous to short-fiber metal matrix composites, where the submicron-grained bands are distributed parallel to the extrusion direction [17]. However, because the composition of the constituents is identical, there is no mismatch in thermal expansion coefficient or modulus between the two regions in the bimodal cryomilled Al alloys. Consequently, the strength difference between two regions arises mainly from the differences in grain size and Orowan strengthening [17]. Several toughening mechanisms have been proposed to explain ductile-phase toughening of composite microstructures, such as crack bridging, crack blunting, crack deflection, stress distribution of crack tip, crack front convolution, local plane stress deformation, etc. On the basis of microstructural characteristics of bimodal cryomilled materials, a model of crack bridging combined with the concept of delamination has been developed, as illustrated in Fig. 2 [17].

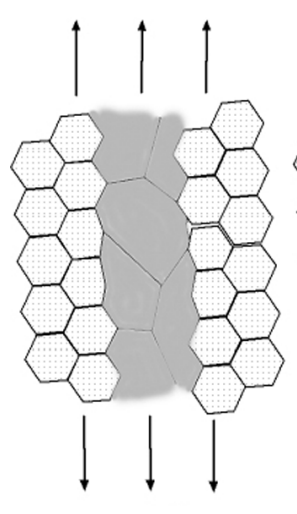

a

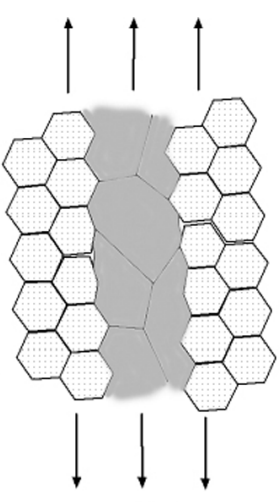

b

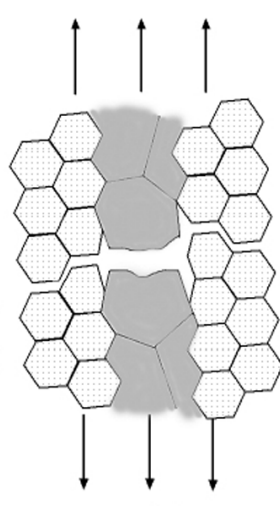

C
Fig. 2. Crack propagation in the bimodal microstructure [17].

In the bimodal materials, microcracks are expected to nucleate first in the harder nanostructured regions and propagate along grain boundaries. When a microcrack meets a submicron-grained band, the band will retard propagation by blunting the crack and/or by delamination of interfaces between submicron-grained and nanostructured-grain regions. When more dislocations are emitted into the ultra-fine grain, a new slip surface may be formed, eventually leading to necking and cavitation within the bands. Finally, dimples on the submicron-grained regions and delamination at interfaces will be generated on the fracture surfaces. The delamination at interfaces and the necking deformation of ductile submicron grain regions will cause significant energy loss, resulting in an enhanced tensile ductility [17].

Introduction of nanoprecipitates in the interior of ultrafine grains is another approach to improve tensile ductility of

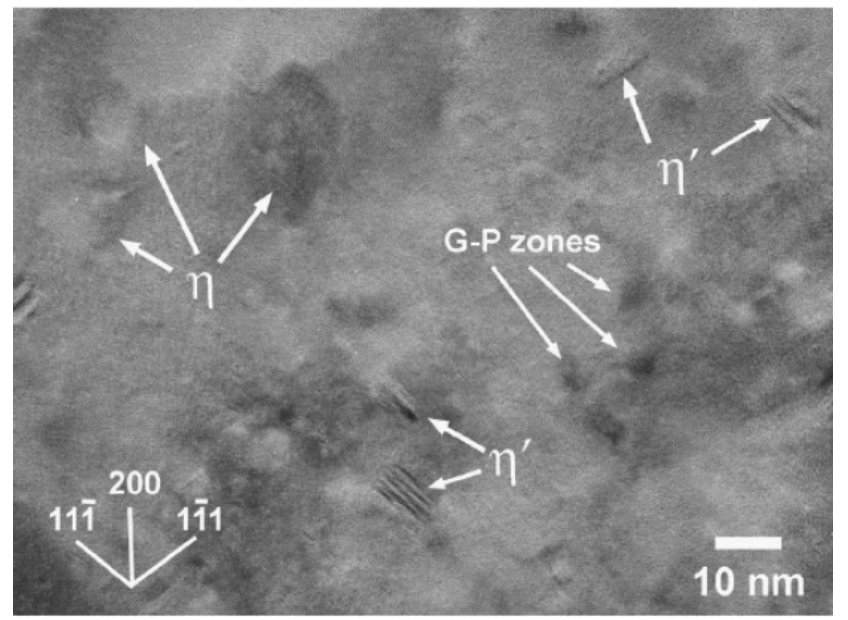

a

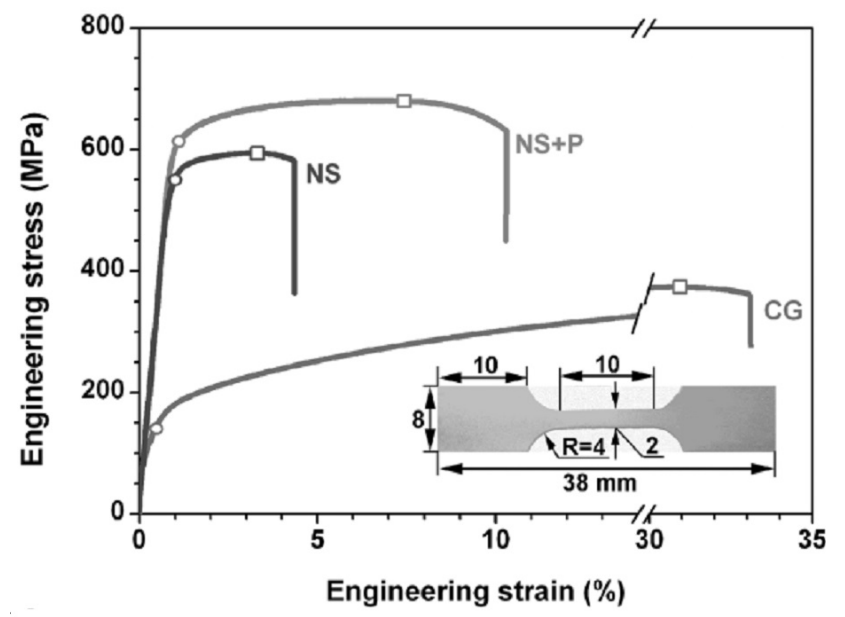

b

Fig. 3. (a) Microstructure of the AA7075 after cryorolling and artificial aging. (b) Engineering stress-strain curves of the coarse-grained (CG), nanostructured (NS), and NS after artificial aging (NS+P samples) of the AA7075. The images are reproduced from [22].

UFG metallic materials [22]. Dislocations are stored in the grain interior due to their interaction with non-shearable nano precipitates, that results in increased strain hardening and, therefore, in enhanced ductility. Nanoscaled precipitates also suppress dislocation glide increasing stress needed for the dislocations to move through the particles which should also increase the yield strength. Nanoscaled precipitates are typically introduced via aging treatment of supersaturated solid solutions with UFG microstructure. For example, a solution treated AA7075 was cryorolled resulting in formation of homogeneous microstructure with the average grain size of $\sim 100 \mathrm{~nm}$ [22]. Then, the material was artificially aged to insert semicoherent metastable $\eta^{\prime}$ and non-coherent stable $\eta$ nanoparticles. The alloy after aging showed higher yield strength compared to that of the cryorolled material (Fig. 3a) as well as increased work hardening rate (Fig. 3b). The yield strength of the material after aging at low temperature increased by $\sim 12 \%$, whereas its uniform elongation doubled. Similar results were demonstrated on other Al alloys, such as AA6063 [23], AA6082 [24], Al-10.8Ag [25], etc.

Introduction of nanotwins into microstructure is another efficient approach to increase both mechanical strength and 

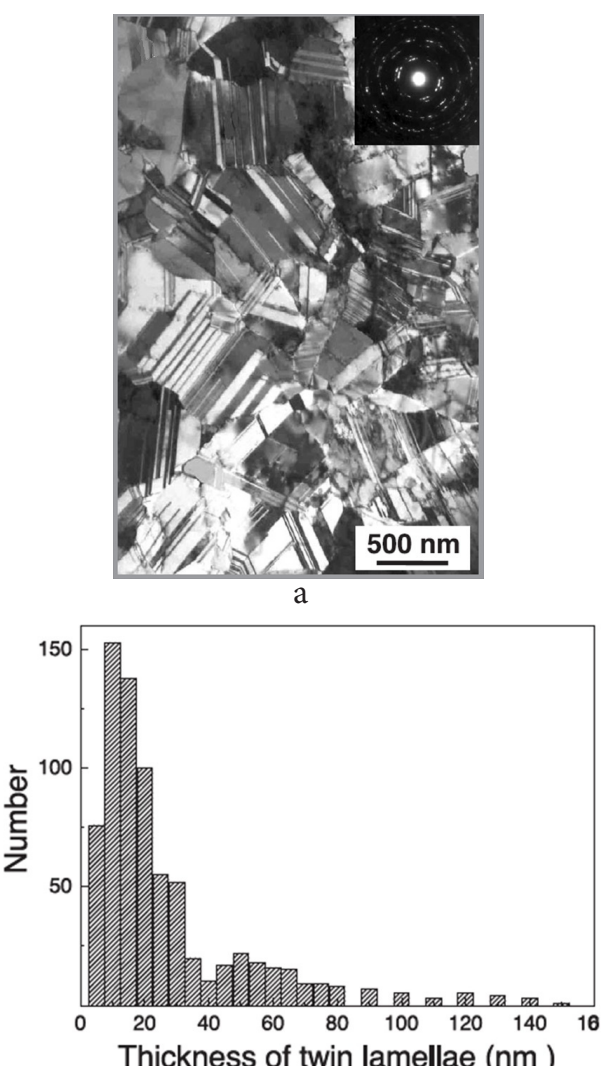

b

Fig. 4. (a) Microstructure of as-deposited pure $\mathrm{Cu}$ with high density nanoscale twins showing high strength and ductility; (b) the statistical distribution for thickness of the twin/matrix lamellae [26].

tensile ductility. As in the previous case, coherent boundaries of nanotwins also serve as storage sites for dislocations. They also have much lower energy and, therefore, they are more stable against migration than high angle grain boundaries. In [26], high density of the nanotwins with the average twin lamella thickness of $15 \mathrm{~nm}$ introduced into pure $\mathrm{Cu}$ (Fig. 4) resulted in extraordinary high yield strength of $900 \mathrm{MPa}$ and ultimate tensile strength of $1068 \mathrm{MPa}$ with elongation to failure of $14 \%$. High density nanotwins can be induced into pure $\mathrm{Cu}$ via dynamic plastic deformation at cryogenic temperatures [27] or using a pulsed electrodeposition technique [28].

Dislocation storage capability in UFG metals is also determined by their stacking fault energy (SFE). Therefore, tayloring SFE via alloying can be another strategy to control ductility. This was clearly demonstrated in series of studies on pure $\mathrm{Cu}$ and $\mathrm{Cu}$ alloys $[29,30]$. Their strength and ductility is improved by decreasing the SFE due to the consequent increase in the strain hardening rate (Fig. 5). The development of profuse twins and stacking faults suppresses dynamic recovery and hinders the annihilation of dislocations. Thus, more twins and stacking faults are produced during tensile testing to accommodate the plastic deformation, the strain hardening rate is thereby enhanced and localized deformation is delayed to increase the uniform elongation with a lowering of the SFE. It was shown that there is an optimal SFE forachieving a maximum uniform elongation in the $\mathrm{Cu}-\mathrm{Al}$ alloys after processing by HPT and $\mathrm{Cu}-\mathrm{Zn}$ after processing by HPT and cold rolling (Fig. 5) [31]. Similar results were also reported for Ni-Co alloys, where Co reduces the SFE

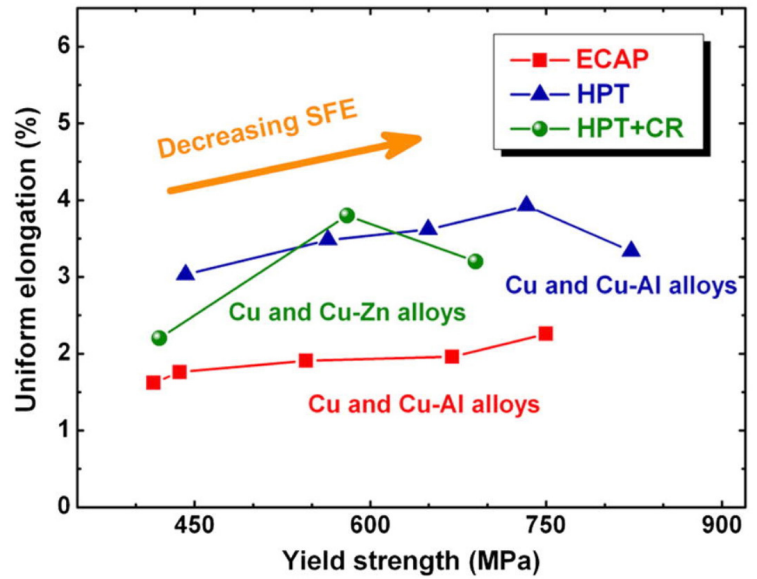

Fig. 5. The relationship between uniform elongation and yield strength for UFG $\mathrm{Cu}$ and $\mathrm{Cu}-\mathrm{Al}$ alloys processed by ECAP and HPT and UFG $\mathrm{Cu}$ and $\mathrm{Cu}-\mathrm{Zn}$ alloys processed by HPT and CR [31].

in $\mathrm{Ni}$ and this promotes grain refinement during processing and increases the dislocation and twin densities. Ultra-fine grains and higher dislocation and pre-existing twin densities provide enhanced mechanical strength, the higher ductility is due to higher work hardening rate [32].

If no nanotwins and/or nanoscale precipitates can be introduced into some UFG materials, their ductility can be improved via reduction of dislocation density. Typically, SPD processed UFG materials have very high dislocation density of $10^{14}-10^{15} \mathrm{~m}^{-2}$, which limits their strain hardening ability, thus degrading their ductility $[2,3]$. Accumulated redundant plastic strain introduced during material processing can reduce dislocation density in the grain interior thereby altering its mechanical behavior. For example, it was demonstrated that ductility of pure $\mathrm{Cu}$ tends to increase with decreasing number of ECAP passes [6,33]. Similar observations were reported for ARB processed pure $\mathrm{Al}$ in [34], where tensile ductility of the material increased with increasing number of ARB passes.

Grain boundary engineering can be another strategy to enhance ductility of the UFG metallic materials. It is well known that misorientation of grain boundaries (GB) can significantly affect mechanical behavior of UFG metals [35]. In [36], it was demonstrated that pure $\mathrm{Cu}$ after HPT processing combined with cold rolling having $56 \%$ high angle grain boundaries (HAGBs) and dislocation density of $4.3 \times 10^{14}$ $\mathrm{m}^{-2}$ shows much higher strength, strain hardening ability and ductility compared to the ECAP processed pure $\mathrm{Cu}$ having $32 \%$ HAGBs and dislocation density of $2.3 \times 10^{14} \mathrm{~m}^{-2}$ (Fig. 6). The higher ductility of the latter material can be related to somewhat lower dislocation density and higher fraction of HAGBs. In several works, observations of enhanced tensile ductility in SPD processed UFG materials were related to non-equilibrium GBs $[2,6,37,38]$. Grain boundary sliding accommodated by grain boundary diffusion mechanism can be activated in the UFG materials if the diffusivity is high [39]. The latter condition can be realized in the UFG metals containing non-equilibrium boundaries defined as GBs with high-angle misorientations and highly defective and disordered structures [2]. Such GBs are typically generated in the UFG metallic materials during SPD processing [2-5]. 


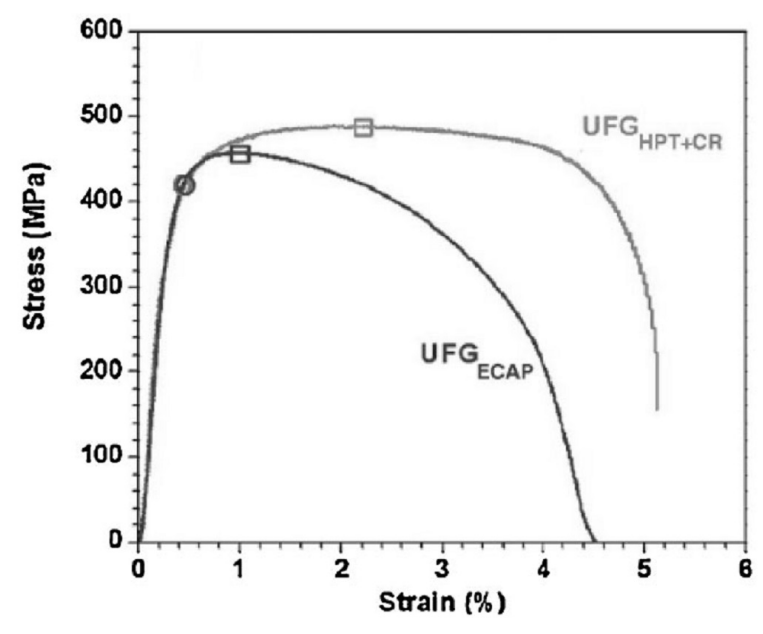

Fig. 6. The tensile stress-strain curves of UFG Cu samples processed by ECAP and HPT combined with cold rolling (HPT-CR) [36].

Transformation induced plasticity (TRIP) effect can be also utilized for enhancement of ductility in the UFG metallic materials with multiphase microstructures [40,41]. In [40], a high strength (>800 MPa yield strength) with an excellent tensile ductility (about $40 \%$ elongation) was achieved in a UFG austenitic FeCrNiMn steel obtained by repetitive thermo-mechanical processing (Fig. 7b). The deformation

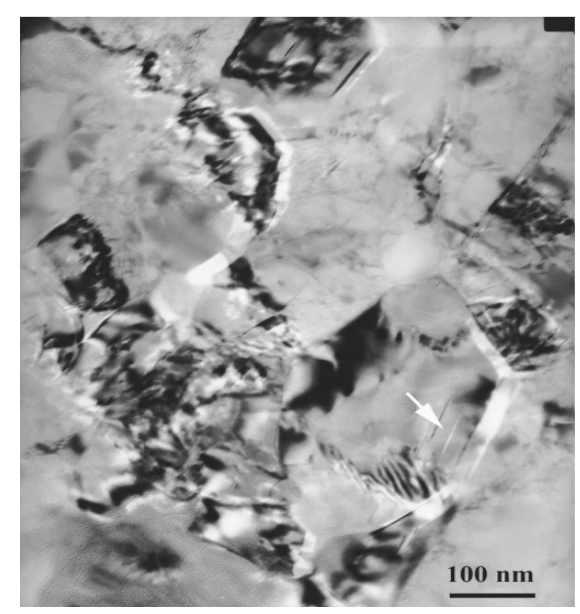

a

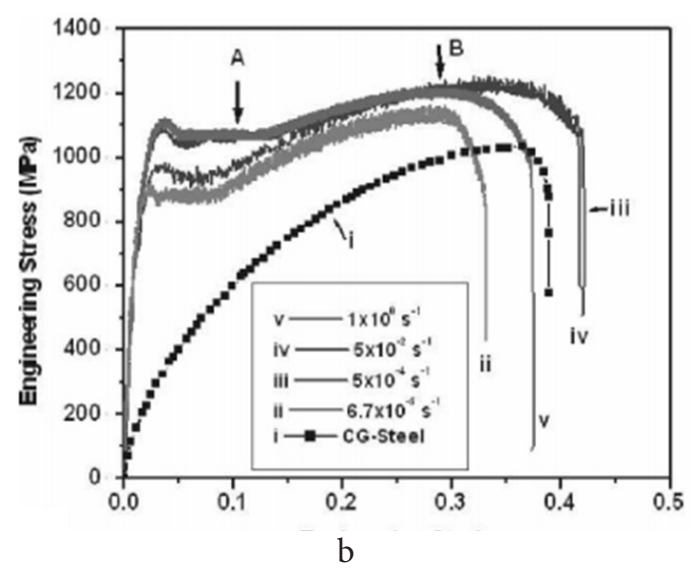

Fig. 7. (a) Microstructure of the UFG FeCrNiMn steel. The white arrow indicates twins formed inside a grain. (b) Tensile engineering stress-strain curves for the steel tested at room temperature and varios strain rates along with the curve for the CG material [40]. mode was found to be dependent on the strain rate. An inhomogeneous deformation occurred in samples tested at strain rates of $5 \times 10^{-2} \mathrm{~s}^{-1}$ and higher, while uniform deformation and phase transformation (Fig. 7a) occurred under strain rates of $5 \times 10^{-3} \mathrm{~s}^{-1}$ and lower resulting in enhanced ductility of the material (Fig. 7b).

\subsection{Strategies to improve ductility of UFG materials based on manipulation with testing parameters}

Testing at high strain rates and/or lower temperatures can be efficient to regain tensile ductility in the UFG metallic materials. In [42], it was demonstrated that by deforming the UFG pure $\mathrm{Cu}$ at cryogenic temperature, tensile uniform elongation is improved (peak is delayed to much larger strains), with also a larger elongation to failure (Fig. 8).

Strain hardening is also pronounced on true stress-strain curves (Fig. 8b). It was shown that low tensile ductility of UFG pure $\mathrm{Cu}$ at room temperature (curve $\mathrm{A}$ on Fig. $1 \mathrm{~b}$ ) is due to dynamic recovery that suppresses the steady-state dislocation storage rate in the grain interior. Testing at cryogenic temperature depressed the annihilation of dislocations at grain boundaries and thermally activated cross slip and climb increasing dislocation density in the grain interior. Increasing the strain rate had also a positive effect in terms of promoting strain hardening. The strain hardening rate increased with increasing strain rate, and as a result, so did the uniform elongation and elongation to failure (Fig. 8a).
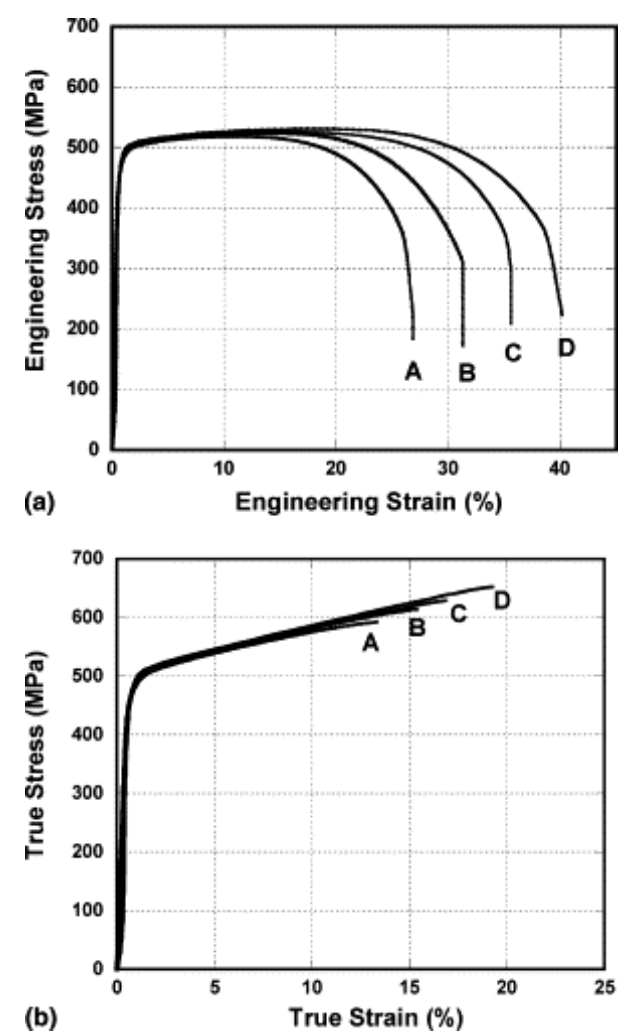

Fig. 8. (a) Tensile engineering stress-strain curves of the ECAP processed UFG Cu tested at $77 \mathrm{~K}$. Curves A-D were tested at strain rates of $10^{-4}, 10^{-3}, 10^{-2}$, and $10^{-1} \mathrm{~s}^{-1}$, respectively. The strain hardening rate, the strain at which the tensile curve peaks, the percentage elongation to failure, as well as the strength, are all higher at $77 \mathrm{~K}$ than at RT (Fig. 1b), and all increase with increasing strain rate [42]. 

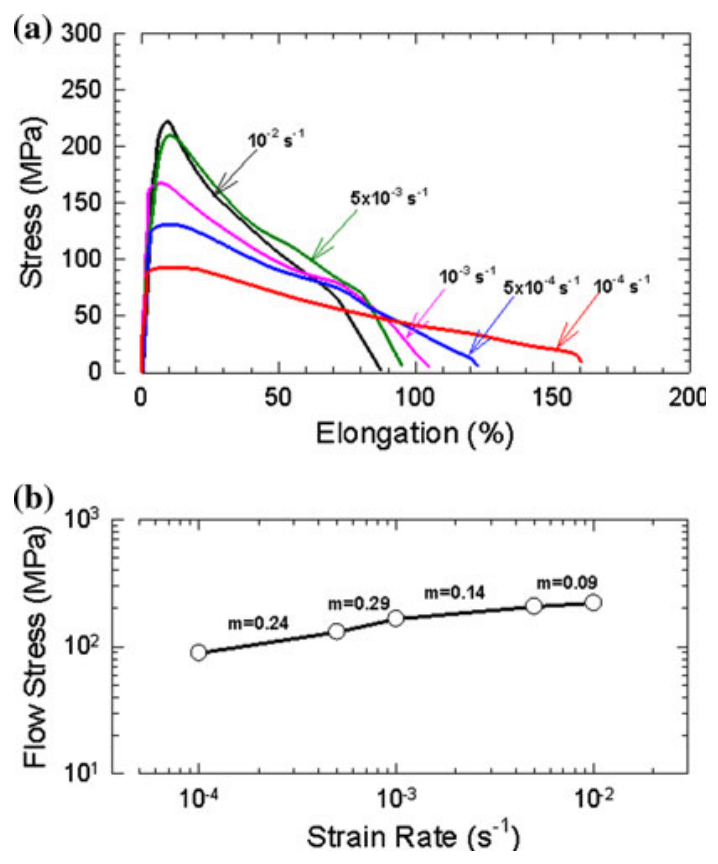

Fig. 9. (a) Effect of strain rate on the true stress-strain curves; (b) the variation of flow stress with strain rate and the values of the strain rate sensitivity for the $\mathrm{Al}-30 \% \mathrm{Zn}$ alloy processed by HPT [38].

Enhanced strain rate sensitivity of the UFG metallic materials with fcc lattice can also somewhat improve tensile ductility. As is well known, these UFG metallic materials are characterized by increased strain rate sensitivity even at low temperatures compared to their coarse-grained counterparts $[10,11]$. Their uniform elongation can be predicted according to the Hart criterion [43]

$$
(d \sigma / d \varepsilon)=(1-m) \sigma
$$

where $d \sigma / d \varepsilon$ is the work hardening rate, $m$ the strain rate sensitivity index and $\sigma$ the flow stress. It follows from Eq. 2 , that a sufficiently large $m$ would help to resist inhomogeneous deformation even in the case if no strain hardening is present. However, even if the strain rate sensitivity of most of UFG metallic materials is enhanced by an order of magnitude
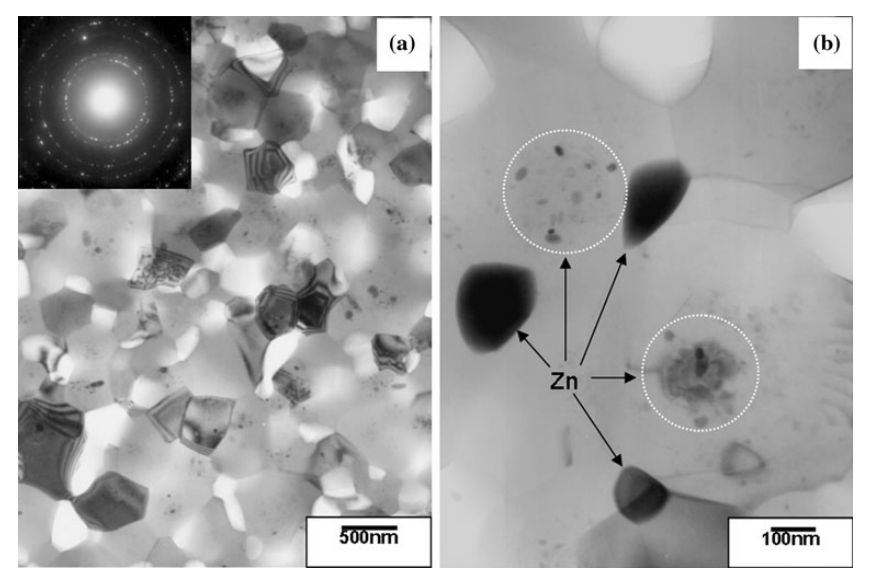

Fig. 10. (a) Microstructure of the Al-30 wt\% $\mathrm{Zn}$ alloy formed in the billet processed by HPT. (b) Zn phase precipitates at triple junctions and within the $\mathrm{Al}$ grains [38]. (to the range of $0.02-0.06$ ), it is still low and its effect on uniform elongation is marginal. Very high strain rate sensitivities in the range of $0.09-0.29$ were achieved in the UFG Al-30\%Zn alloy obtained via HPT processing in [38]. Mechanical behaviour of this material at room temperature had several features including: (i) extremely high values of uniform elongation reaching $160 \%$ at strain rate of $10^{-4} \mathrm{~s}^{-1}$ (Fig. 9a); (ii) strong effect of strain rate on true-stress strain curves (Fig. 9a); (iii) extensive grain boundary sliding with contribution into total elongation varying in the range of $40-60 \%$. This unusual behaviour was attributed to the development of thin layers of a $\mathrm{Zn}$-rich grain boundary phase leading to extensive grain boundary sliding (Fig. 10) [38].

There can be also a significant effect of stress state on ductility/formability of the UFG materials. In [44], it was demonstrated that necking in the UFG Pd and Pd-Ag alloys leads to activation of cooperative grain boundary sliding and micro shear banding in the necked region, whereas these deformation mechanisms were not active in the region of homogeneous plastic flow. Therefore, it can be suggested that stress state can affect mechanisms operating during plastic deformation of the UFG metallic materials, which in turn can influence their ductility. In most of metalforming operations, material is deformed in multiaxial mode (when mean stress is increased) along complex strain path. In [45], it was demonstrated that high strength UFG Cu can show the same level of formability in biaxial stretching as its coarse-grained counterpart (Fig. 11a), despite the uniaxial tensile ductility of the UFG $\mathrm{Cu}$ is much lower (Fig. 11b). Enhanced formability in biaxial stretching was related to profuse micro-shear banding in biaxial stretching of the UFG processed $\mathrm{Cu}$ providing significant amount of plastic deformation and, therefore, formability, that does not occur during uniaxial tensile testing of the UFG pure Cu [41]. In [46], cryorolled UFG Al was successfully roll formed into simple longitudinal sections having profile radii of $15 \mathrm{~mm}$ despite its low uniaxial tensile elongation and limited hardening in tension.

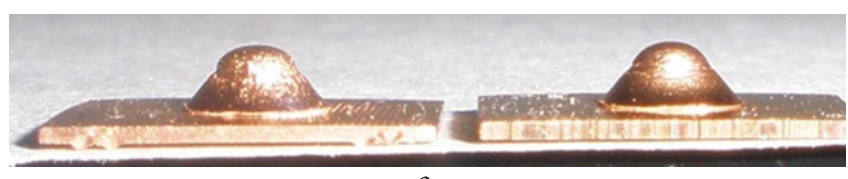

a

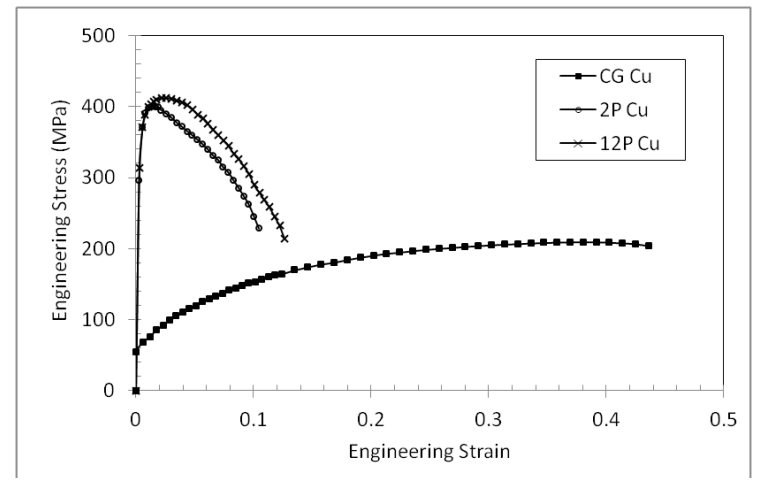

$\mathrm{b}$

Fig. 11. (a) Specimens after small punch testing: left - coarse grained pure $\mathrm{Cu}$, right - pure $\mathrm{Cu}$ after 2 ECAP passes. (b) Engineering stress-strain curves from uniaxial tensile testing of $\mathrm{CG} \mathrm{Cu}$ and ECAP processed $\mathrm{Cu}$ (2 and 12 passes) [45]. 


\section{Summary and conclusions}

1. The UFG metallic materials typically exhibit high mechanical strength and low tensile ductility, which severely limits their practical utility. Numerous strategies have been developed to improve their ductility. Using these strategies now, tensile ductility of the UFG metallic materials can be restored to the level of ductility of their coarse-grained counterparts and even to the higher levels.

2. The strategies to improve tensile ductility are based either on idea of intelligent microstructural design in the UFG materials, or on manipulation with testing parameters (temperature, strain rate, stress mode) to improve the strain hardening ability of the materials and delay the onset of necking.

3. The UFG metallic materials can demonstrate enhanced formability in deformation under complex stress state even if their uniaxial tensile ductility is very low. This is related to activation of deformation mechanisms promoting ductility, which are not active during uniaxial tensile testing.

Acknowledgements. The author would like to acknowledge gratefully the Spanish Ministry of Economy and Competitiveness for financial support through the Ramon y Cajal Fellowship.

\section{References}

1. T. G. Langdon, Acta Mater. 61, 7035 (2013).

2. R.Z. Valiev, Nature Mater. 3, 511 (2014)

3. R.Z. Valiev, R. K. Islamgaliev, I. V. Alexandrov, Prog. Mater. Sci. 45, 103 (2001).

4. R.Z. Valiev, T.G. Langdon, Prog. Mater. Sci. 51, 881 (2006).

5. A.P. Zhilyaev, T.G. Langdon, Prog. Mater. Sci. 53, 893 (2008).

6. R.Z. Valiev, I. V. Alexandrov, Y.T. Zhu, T.C. Lowe, J. Mater. Res. 5, 17 (2002).

7. Y. T. Zhu, X.Z. Liao, Nature Mater. 3, 351 (2004).

8. D. Jia, Y.M. Wang, K.T. Ramesh, E. Ma, Y.T. Zhu, R.Z. Valiev, Appl. Phys. Lett. 79, 611 (2001).

9. Z. Budrovic, H. Van Swygenhoven, P.M. Derlet, S. V. Petegem, B. Schmitt, Science 304, 273 (2004).

10. E. Ma, JOM 54, 49 (2006).

11. Y. Zhao, Y. T. Zhu, E. J. Lavernia, Adv. Eng. Mater. 12, 769 (2010).

12. I. A. Ovid'ko, T. G. Langdon, Rev. Adv. Mater. Sci. 30, 103 (2012).

13. Y. Wang, M. Chen, F. Zhou, E. Ma, Nature. 419, 912 (2002)

14. B. R. Kumar, D. Raabe. Scripta Mater. 66, 634 (2012).

15. B. Q. Han, J. Y. Huang, Y. T. Zhu, E. J. Lavernia, Acta Mater. 54, 3015 (2006).

16. D. Witkin, Z. Lee, R. Rodriguez, S. Nutt, E. Lavernia, Scripta Mater. 49, 297 (2003).

17. Z. Lee, R. Rodriguez, R. W. Hayes, E. J. Lavernia, S. R. Nutt, Metall. Mater. Trans. A 34, 1473 (2003).

18. Z. Lee, V. Radmilovic, B. Ahn, E. J. Lavernia, S. R. Nutt, Metall. Mater. Trans. A 41, 795 (2010).

19. B. Q. Han, Z. Lee, D. Witkin, S. Nutt, E. J. Lavernia, Metall.
Mater. Trans. A 36957 (2005).

20. D. Witkin, B. Q. Han, E. J. Lavernia, Metal. Mater. Trans. A 37, 185 (2006).

21. B. Q. Han, F. A. Mohamed, E. J. Lavernia, J. Mater. Sci. 383319 (2003).

22. Y.H. Zhao, X.Z. Liao, S. Cheng, E. Ma, Y.T. Zhu. Adv. Mater. 18, 2280 (2006).

23. S. K. Panigrahi, R. Jayaganthan, Metal. Mater. Trans. A 412675 (2010).

24. S. Dadbakhsh, A. Karimi Taheri, C.W. Smith, Mater. Sci. Eng. A 527, 4758 (2010).

25. Z. Horita, K. Ohashi, T. Fujita, K. Kaneko, T. G. Langdon, Adv. Mater. 17, 1599 (2005).

26. L. Lu, X. Shen, X. Huang, K. Lu. Science 323, 607 (2009).

27. Y.S. Li, N. R. Tao, K. Lu. Acta Mater. 56, 230 (2008).

28. L. Lu, Y. Shen, X. Chen, L. Qian, K. Lu. Science 304, 422 (2004).

29. S. Qu, X.H. An, H.J. Yang, C.X. Huang, G. Yang, Q. S. Zang, Z. G. Wang, S. D. Wu, Z. F. Zhang. Acta Mater. 571586 (2009).

30. Y.H. Zhao, X. Z. Liao, Z. Horita, T. G. Langdon, Y. T. Zhu. Mater. Sci.Eng. A. 493, 123 (2008).

31. X. H. An, Q. Y. Lin, S. D. Wu, Z. F. Zhang, R. B. Figueiredo, N. Gao, T. G. Langdon. Scripta Mater. 64954 (2011).

32. P. L. Sun, Y.H. Zhao, J. C. Cooley, M. E. Kassner, Z. Horita, T. G. Langdon, E. J. Lavernia, Y. T. Zhu. Mater. Sci. Eng. A. 52583 (2009).

33. F. Dalla Torre, R. Lapovok, J. Sandlin, P.F. Thomson, C.H. J. Davies, E.V. Pereloma. Acta Mater. 52, 4819 (2004).

34. H. W. Hoeppel, J. May, M. Goeken. Adv.Eng. Mater. 6, 781 (2004).

35. R. Kapoor, N. Kumar, R.S. Mishra, C.S. Huskamp, K. K. Sankaran, Mater. Sci. Eng. A 527, 5246 (2010).

36. Y.H. Zhao, J.F. Bingert, Y.T. Zhu, X.Z. Liao, R. Z. Valiev, Z. Horita, T. G. Langdon, Y.Z. Zhou, E. J. Lavernia. Appl. Phys. Lett. 92, 081903 (2008).

37. P. Kumar, C. Xu, T.G. Langdon. J. Mater. Sci. 44, 3913 (2009).

38. R.Z. Valiev, M.Yu. Murashkin, A. Kilmametov, B. Straumal, N. Q. Chinh, T. G. Langdon. J. Mater. Sci. 45, 4718 (2010).

39. Y. Champion, C. Langlois, S. Guerin-Mailly, P. Langlois, J. L. Bonnentien, M. J. Hytch. Science. 300, 310 (2003).

40. S. Cheng, H. Choo, Y.H. Zhao, X.L. Wang, Y.T. Zhu, Y. D. Wang, J. Almer, P. K. Liaw, J. E. Jin, Y. K. Lee, J. Mater. Res. 23, 1578 (2008).

41. K. Tao, H. Choo, H. Li, B. Claussen, J.E. Jin, Y. K. Lee. Appl. Phys. Lett. 89, 212906 (2006).

42. Y. M. Wang, E. Ma. Acta Mater. 521699 (2004).

43. E. V. Hart, Acta Metall. Mater. 15, 351 (1967).

44. K. Yang, Yu. Ivanisenko, A. Caron, A. Chuvilin, L. Kurmanaeva, T. Scherer, R.Z. Valiev, H. J. Fecht, Acta Mater. 58, 967 (2010).

45. E.C. Moreno-Valle, M.A. Monclus, J.M. MolinaAldareguia, N. Enikeev, I. Sabirov. Metall. Mater. Trans. A. 44, 2399 (2013).

46. J. Marnette, M. Weiss, P. D. Hodgson, Mater. Des. 63, 471 (2014). 